\title{
STUDI PEMINATAN PENULISAN KREATIF DAN PEMINATAN JURNALISTIK PADA PROGRAM STUDI PENERBITAN
}

\author{
Jimmy Paat \\ Program Studi Penerbitan, Jurusan Penerbitan \\ Politeknik Negeri Media Kreatif Jakarta \\ Surel: jimmypaat@yahoo.com
}

\begin{abstract}
:
The purpose of this research are to (1) provide a reason academic formation of creative writing and journalism concentration, (2) describe the structure of the curriculum design creative writing and journalism concentration, (3) lays out the work prospects of graduates creative writing and journalism concentration, and (4) describe the level of student interest in courses of creative writing and journalism concentration in the department of Publishing in Polimedia. Researcher uses document study to draft a new curriculum structure design creative writing and journalism concentration. Furthermore, to study the interest of students towards creative writing and journalism, he uses a quantitative descriptive research. The results obtained, creative writing and journalism specification need to be held because the two concentrations give much interest to students, needed and in accordance with the development of the science publishing in Indonesia.
\end{abstract}

Keywords: creative writing, journalism, concentration

\section{PENDAHULUAN}

\begin{tabular}{lll}
\multicolumn{2}{c}{ Penelitian bertujuan untuk } & terfokus pada terwujudkannya suatu \\
mengkaji peminatan Penulisan & kondisi dengan memperhitungkan \\
Kreatif dan peminatan Jurnalistik & kemampuan dasar, bakat, minat, dan \\
pada Prodi Penerbitan Politeknik & kecenderungan pribadi individu. \\
Negeri Media Kreatif sehingga & \multicolumn{1}{c}{ Dalam dunia pendidikan, } \\
diharapkan dapat memberikan & peminatan siswa pertama-tama \\
perspektif baru dalam pembelajaran & terarah pada peminatan studi dan \\
pada Prodi Penerbitan. Studi & karir atau pekerjaan. Peminatan pada \\
peminatan Penulisan Kreatif dan & siswa dikembangkan dan diwujudkan \\
Peminatan Jurnalistik ini didasarkan & didasarkan pada potensi atau kondisi \\
pada kebutuhan mahasiswa, dosen, & yang ada pada diri individu itu \\
dan industri. & sendiri, dan kedua dipengaruhi \\
Peminatan berasal dari kata & secara langsung atau tidak langsung \\
minat yang berarti kecenderungan & oleh kondisi lingkungan, baik yang \\
atau keinginan yang cukup kuat & bersifat natural, kehidupan keluarga, \\
berkembang pada diri individu yang & kelompok, masyarakat dan budaya,
\end{tabular}


maupun secara khusus fasilitas pendidikan yang diperoleh siswa.

Untuk setiap tingkat peminatan siswa digunakan lima aspek pokok sebagai dasar pertimbangan bagi arah peminatan yang akan ditempuh. Kelima aspek tersebut secara langsung mengacu kepada karakteristik pribadi siswa dan lingkungannya, kondisi satuan pendidikan dan kondisi pihak-pihak yang bertanggung jawab atas pendidikan siswa yang bersangkutan, dikaitkan pada konstruk dan isi kurikulum yang ada, yaitu:

1. Potensi dasar umum (kecerdasan), yaitu kemampuan dasar yang biasanya diukur dengan tes intelegensi.

2. Bakat, minat dan kecenderungan pribadi yang dapat diukur dengan tes bakat dan/atau inventori tentang bakat/minat.

3. Konstruk dan isi kurikulum yang memuat mata pelajaran dan/atau praktik/latihan yang dapat diambil/didalami siswa atas dasar pilihan, serta sistem Satuan Kredit Semester (SKS) yang dilaksanakan.

4. Prestasi hasil belajar, yaitu nilai hasil belajar yang diperoleh siswa di satuan pendidikan, baik

(a) rata-rata pada umumnya, maupun (b) per mata pelajaran, baik yang bersifat wajib maupun pilihan, dalam rangka peminatan akademik, vokasional dan studi lanjutan.

5. Ketersediaan fasilitas satuan pendidikan, yaitu apa yang ada di tempat siswa belajar yang dapat menunjang pilihan atau arah peminatan mereka.

6. Dorongan moral dan finansial, yaitu kemungkinan penguatan dari berbagai sumber yang dapat membantu siswa, seperti orang tua dan kemungkinan bantuan dari pihak lain, dan siswa.

Kent. Prent dkk. dalam Masri Sareb Putra (2010) menjelaskan bahwa Creative writing ditilik dari etimologi berasal dari kata creative dan writing. Creative berasal dari kata Latin creatio yang berarti ciptaan, makhluk, alam ciptaan. Adapun writing berarti tulisan. Jadi, Creative writing ialah tulisan terstruktur yang sarat dengan ide-ide baru (inovatif) yang menghibur, berguna, dan mencerahkan (bdk. Horatius, pujangga Romawi kuna yang menyatakan bahwa karya sastra (ars scribendi) yang baik mengandung dua unsur sekaligus yakni dulce (indah) dan utile (berguna).

Creative dapat dimengerti sebagai (1) Menggerakkan, membangun, mencipta, dan menghasilkan "karya kreatif" dan inovatif, (2) Mempunyai kemampuan, atau daya, untuk mencipta suatu karya imaginatif ( $a$ creative imagination), (3) Konsep, desain, dan artwork dalam dunia periklanan. Dalam sebuah tulisan kreatif, dapat direkonstruksi pemikiran penulisnya: alur, logika, validitas, kesahihan, kebenaran, maupun sudut pandangnya. Karena itu, keterampilan menulis tidak dapat 
dipisahkan dari keterampilan berpikir.

Terminologi antara menulis dan mengarang sebaiknya dibedakan karena dilihat dari proses kreatifnya, keduanya berbeda. Menulis ialah proses kreatif menghasilkan tulisan nonfiksi, sedangkan mengarang ialah proses di dalam menghasilkan tulisan fiksi. Menulis dapat distrategikan, tidak harus menunggu ide datang. Jika tahap invention (menemukan ide atau topik yang hendak ditulis) sudah dilakukan, sementara bahan-bahan sudah siap maka proses menulis sudah dapat dimulai. Sementara mengarang kerap harus menunggu ilham datang karena namanya juga mengarang maka proses penciptaannya jauh lebih rumit dan memakan waktu. Akan tetapi, dilihat dari proses kreatif atau mata rantai penciptaan, baik menulis maupun mengarang sama saja. Kedua proses kreatif terkait menulis dan mengarang hampir sama dengan proses retorika.

Proses kreatif, hingga dihasilkannya sebuah tulisan yang baik, dapat diibaratkan dengan membangun sebuah rumah. Mulai dari membangun fondasi hingga finishing, sebuah rumah melalui tahap-tahap penyelesaian. Ketika sudah jadi, materi atau bahan rumah itu tidak lagi terpisah, melainkan menjadi satu kesatuan yang utuh. Sementara topik tetap fokus, tidak melebar, sebagaimana tampak dalam gambar berikut ini. Gaya selingkung Tempo menyebut kesetiaan pada topik ini sebagai "unting-unting".
Proses kreatif menulis mengikuti enam tahap yakni invention, collection, organization, drafting, revising, dan proofreading.

Menurut Onong Uchjana dalam bukunya Nurdin Sistem Komunikasi Indonesia, (2005), istilah jurnalistik berasal dari bahasa Belanda journalistiek. Seperti halnya istilah bahasa Inggris journalism yang bersumber pada perkataan journal, ini merupakan terjemahan dari bahasa Latin diurna berarti harian atau setiap hari.

Selanjutnya jurnalistik dapat disebut adalah suatu pengelolaan harian yang menarik minat khalayak mulai dari peliputan sampai penyebarannya kepada masyarakat. Apa saja yang terjadi di dunia, apakah peristiwa itu faktual (fact) atau pendapat seseorang (opinion), jika diperkirakan akan menarik perhatian khalayak, akan merupakan bahan dasar bagi jurnalistik; akan menjadi bahan berita untuk disebar luaskan kepada masyarakat.

Menurut Mondry dalam bukunya Pemahaman Teori dan Praktik Jurnalistik (2008), yang disebut Journalist atau wartawan adalah seorang petugas media massa surat kabar, majalah, radio, atau televisi yang profesinya mengelola pemberitaan yakni meliput peristiwa yang terjadi di masyarakat, menyusun kisah berita, dan menyebarkan berita, dan menyebarkan berita yang sudah tuntas kepada masyarakat. 
Oleh karena itu diperlukan kajian untuk mendapatkan alasan akademis terhadap pengadaan peminatan Penulisan Kreatif dan peminatan Jurnalistik, rancangan struktur kurikulum peminatan Penulisan Kreatif dan peminatan Jurnalistik, prospek kerja lulusan peminatan Penulisan Kreatif dan peminatan Jurnalistik serta deskripsi tingkat ketertarikan mahasiswa prodi Penerbitan terhadap peminatan Penulisan Kreatif dan peminatan Jurnalistik yang akan dimulai pada tahun akademik 2014 di Polimedia.

\section{METODE PENELITIAN}

Penelitian ini dilaksanakan di Politeknik Negeri Media Kreatif Jakarta selama tiga bulan mulai September sampai November 2014. Untuk menjawab rumusan masalah 1, 2, dan 3, peneliti menerapkan metode diskusi panel melalui presentasi rancangan kurikulum dan mendapatkan feedback dari narasumber. Brainstroming, untuk menghimpun pendapat dan pikiranpikiran dari narasumber dan para peserta sebagai pengambil kebijakan untuk disublimasikan ke dalam penyusunan kurikulum dan silabus. Diskusi untuk sharing pendapat dari para narasumber dan peserta untuk menambah wawasan dan landasan pengembangan substansi bagi dosen di program studi Penerbitan, Politeknik Negeri Media Kreatif. Tahapan ini didasarkan dari teori Effi Aswita Lubis dalam bukunya Metode Penelitian Pendidikan (2012).
Peneliti menggunakan metode rekam jejak terhadap draf rancangan struktur kurikulum peminatan Penulisan Kreatif dan Jurnalistik. Selanjutnya, untuk mempelajari ketertarikan mahasiswa terhadap peminatan Penulisan Kreatif dan Jurnalistik, peneliti menggunakan studi deskriptif. Pertama, peneliti merancang dan mengadministrasikan survei tertulis. Kemudian, mahasiswa diberikan sejumlah pertanyaan yang cara menjawabnya dengan berbagai macam, yaitu dengan cara memilih, pertanyaan tertutup, pertanyaan terbuka untuk memudahkan analisis. Metode tersebut dipilih karena peneliti, ingin memperoleh informasi secara langsung dari mahasiswa mengenai pilihan mereka. Metode yang digunakan diusahakan tidak bersifat memaksa agar mereka secara sukarela mengisi angket yang diberikan. Tidak ada wawancara langsung, sehingga partisipan secara tidak langsung dilindungi.

Instrumen penelitian mencakup (1) studi dokumen terhadap draf rancangan struktur kurikulum peminatan Penulisan Kreatif dan peminatan Jurnalistik, (2) angket dan wawancara tentang analisis kebutuhan mahasiswa, dosen, dan industri. Dalam hal ini, peneliti akan menggunakan dua narasumber yang ahli di bidangnya, yakni R. Masri Putra Sareb (Penulis dan Dosen UMN) dan Ahmadun Yosi Herfanda (Dosen dan Jurnalis). Tujuannya adalah untuk mendapatkan uji validitas rancangan struktur kurikulum. 
Validitas instrumen penelitian dilakukan melalui validitas isi. Instrumen penelitian berupa daftar pengecekan (checklist) dan angket diminta rekan sejawat peneliti untuk menilai kevaliditasannya. Instrumen penelitian tersebut disusun dengan mengacu kepada konsep yang dikemukakan oleh Alan Cunningsworth dan Jack C. Richards. Reliabilitas instrumen penelitian dilakukan dengan cara tesretes. Instrumen yang diuji reliabilitas dengan cara tes-retes ini berupa angket analisis kebutuhan mahasiswa dan dosen. Angket diberikan kepada seluruh mahasiswa aktif program studi Penerbitan, lima orang dosen Penerbitan, dan tiga praktisi. Untuk instrumen yang berkaitan dengan data kualitatif, dilakukan pengecekan keabsahan data.

Data penelitian terdiri atas (1) data rancangan struktur kurikulum peminatan Penulisan Kreatif dan Jurnalistik dan (2) data survei peminatan mahasiswa. Data pertama diperoleh dari rekam jejak dan data kedua yaitu analisis hasil survei dengan metode kualitatif deskriptif dengan tambahan persentase angka hasil survei peminatan.

\section{HASIL DAN PEMBAHASAN}

\section{Alasan Perlunya Peminatan Penulisan Kreatif dan Jurnalistik}

Dinamika kemajuan teknologi dan informasi telah mengakibatkan perubahan dalam semua strata kehidupan masyarakat, baik di bidang industri sosial, budaya, politik, moral/etika dan tak kecuali dalam bidang pendidikan.

Dalam hal merespon perubahan ini, dunia pendidikan dituntut mampu menata sistem pendidikan yang memungkinkan output pendidikan siap menghadapi tantangan masa depannya. Tujuan pendidikan yang diharapkan seperti yang dicanangkan oleh UNESCO haruslah mencapai the four pillars of education, yaitu learning to know (belajar mengetahui), learning to do (belajar untuk berbuat), learning to be or capable (belajar untuk menjadi/ berkemampuan) dan learning to live together (belajar untuk hidup bersama).

Untuk mencapai tujuan pendidikan tersebut, pemerintah telah mengeluarkan kebijakan-kebijakan dalam Undang-Undang pendidikan, di antaranya adalah Undang-Undang Nomor 22 tahun 1999 tentang otonomi daerah dalam bidang pendidikan dan kebudayaan, yang selanjutnya dipertegas dalam Undang-Undang Sistem Pendidikan Nasional Nomor 20 tahun 2003 (pasal 36) bahwa pengembangan kurikulum dilakukan dengan mengacu pada standar nasional pendidikan (SNP) untuk mewujudkan tujuan pendidikan nasional (ayat 1). Kurikulum pada semua jenjang dan jenis pendidikan dikembangkan dengan prinsip diversifikasi sesuai dengan satuan pendidikan, potensi daerah dan siswa (ayat 2).

Lebih jauh di dalam pasal 38 ayat 3 dan 4 dikemukakan bahwa 
"kurikulum pendidikan tinggi dikembangkan oleh perguruan tinggi yang bersangkutan dengan mengacu pada standar nasional pendidikan untuk setiap program studi“ (ayat 3). "Kerangka dasar dan struktur kurikulum pendidikan tinggi dikembangkan oleh perguruan tinggi yang bersangkutan dengan mengacu pada standar nasional pendidikan untuk setiap program studi" (ayat 4).

Terkait dengan UU Sisdiknas pasal 38 di atas, program studi Penerbitan sebagai salah satu prodi di jurusan Penerbitan Politeknik Negeri Media Kreatif, berupaya melakukan evaluasi dan revisi terhadap kurikulum yang ada dan mengembangkan ke kurikulum yang berorientasi kepada pencapaian kompetensi pembelajaran anak. Dalam pengembangan validasi kurikulum Prodi Penerbitan diharapkan output setidaknya memiliki beberapa kompetensi yang dapat dikelompokkan pada:

1. Penguasaan landasan dan wawasan pendidikan, yaitu penguasaan landasan wawasan dan pengetahuan sektor industri kreatif bidang penerbitan.

2. Penguasaan substansi kajian bidang penerbitan yang terkait penguasaan substansi kajian setiap matakuliah; penguasaan isi dan bahan ajar setiap matakuliah dan penguasaan cara pengembangan bahan ajar matakuliah bersangkutan
3. Penguasaan pembelajaran bidang studi yang mendidik, terkait kemampuan mengidentifikasi karakteristik siswa, penguasaan penyusunan rancangan belajar bidang studi yang mendidik, penguasaan penetapan strategi pembelajaran bidang studi, kemampuan melaksanakan pembelajaran bidang studi yang mendidik, kemampuan merencana dan melaksana evaluasi proses dan hasil belajar. bidang studi, penguasaan perencanaan dan pelaksanaan penelitian untuk peningkatan mutu pembelajaran bidang studi, serta kemampuan mengelola dan memanfaatkan laboratorium Penerbitan untuk memperkuat pengalaman belajar

4. Penguasaan pengelolaan satuan matakuliah, terkait kemampuan merencanakan program, kemampuan mengorganisir komponen matakuliah, kemampuan melaksanakan program matakuliah, kemampuan melakukan supervisi, monitoring dan evaluasi program, serta kemampuan mengembangkan inovasi program dan bentuk penyelenggaraan bidang studi.

5. Pengembangan kepribadian dan keprofesionalan sebagai dosen, yang menyangkut kemampuan menyesuaikan diri dengan lingkungan kerja, kemampuan bekerja secara mandiri dan mengadakan kemitraan. 


\section{Rancangan Struktur Kurikulum Peminatan Penulisan Kreatif dan Jurnalistik}

Berikut adalah rancangan struktur kurikulum peminatan Penulisan Kreatif dan peminatan Jurnalistik pada Prodi Penerbitan. Rancangan ini telah mendapat masukan dari dua narasumber yang peneliti libatkan dalam penyusunan studi peminatan ini.

\section{Peminatan Penulisan Kreatif}

Dilihat dari proses penyusunannya, kurikulum ini sudah sahih sebab telah melalui penelitian yang melibatkan: 1) praktisi, 2) pengguna (stakeholder), dan 3) akademisi.Sudah tepat langkahnya, setiap 5 tahun sekali kurikulum ditinjau ulang, disesuaikan dengan perubahan masyarakat dan tuntutan dunia industri. Bangun strukturnya sudah sesuai. Meski tidak diperinci, namun dapat diketahui dengan jelas mana matakuliah yang masuk pengembangan kepribadian, keterampilan berkarya, serta keterampilan dan keahlian. Tampak juga di dalam struktur kurikulum itu core competence lulusan sehingga dapat dibayangkan profil lulusannya serta akan bekerja di mana, sebagai apa nantinya mereka setelah lulus.

Secara umum, sudah sesuai dengan konsentrasi yang dimaksudkan, mengerucut jelas, mana matakuliah yang menjadi prasyarat matakuliah lain karena sebelumnya sudah didiskusikan matang. Hanya pembobotan SKS saja yang akan diberikan masukan, termasuk substansi materi yang wajib diberikan di masing-masing matakuliah. Dalam buku Principle of Creative Writing karya R. Masri Sareb Putra (2010), dijelaskan berbagai teori tentang penulisan kreatif. Rancangan kurikulum pada Tabel 1, 2, dan 3 ini sudah sesuai dengan pemaparan narasumber.

Tabel 1 Matakuliah Semester IV

\begin{tabular}{clc}
\hline No & Matakuliah & SKS \\
\hline 1 & Pengantar Penulisan & 2 \\
& Kreatif & \\
2 & Penulisan Cerita Pendek & 2 \\
3 & Pemasaran Penerbitan & 2 \\
4 & Kewirausahaan & 3 \\
5 & Kalkulasi Penerbitan & 3 \\
6 & Digital Grafis & 3 \\
7 & Penyuntingan Isi & 3 \\
8 & Resensi Buku, Film, dan & 2 \\
& Musik & \\
9 & Penulisan Profil/Biografi & 2 \\
\hline Jumlah SKS & 23 \\
\hline
\end{tabular}

Tabel 2 Matakuliah Semester V

\begin{tabular}{lll}
\hline No & Matakuliah & SKS \\
\hline 1 & Desain Media & 3 \\
2 & Kewirausahaan & 3 \\
& $\begin{array}{l}\text { Penerbitan } \\
3\end{array}$ & Pemasaran Penerbitan \\
& Terpadu & 3 \\
4 & Teknik Penulisan & 2 \\
& Laporan & \\
5 & Penyuntingan Kreatif & 3 \\
6 & Penulisan Novel & 2 \\
7 & Penulisan Komik & 2 \\
8 & Produksi Penerbitan & 3 \\
9 & Copy Writing & 3 \\
\hline Jumlah SKS & 24 \\
\hline
\end{tabular}


Tabel 3 Matakuliah Semester VI

\begin{tabular}{lll}
\hline No & Matakuliah & SKS \\
\hline 1 & Praktik Industri & 4 \\
2 & Tugas Akhir & 6 \\
\hline Jumlah SKS & 10 \\
\hline
\end{tabular}

Peminatan Jurnalistik

Menurut AY. Herfanda, setelah menyimak rancangan kurikulum Konsentrasi Jurnalistik yang telah disiapkan oleh peneliti, menurut saya jumlah dan ragam matakuliah dalam lingkup bidang jurnalistik sudah cukup memadai untuk mencetak lulusan yang menguasai teori dan praktik (terampil) jurnalistik serta memiliki wawasan yang cukup memadai tentang jurnalistik. Hanya tinggal menambah matakuliah Teknik Menulis Feature untuk menggantikan matakuliah Tipologi Karya Jurnalistik (semester IV), sedangkan topik Tipologi Karya Jurnalistik cukup menjadi bagian dari matakuliah Teknik Penulisan Berita, yakni sebagai pengantar matakuliah ini.

Pembekalan bagi mahasiswa Konsentrasi Jurnalistik saya anggap cukup dengan 12 matakuliah yang diberikan pada semester IV dan V tersebut, karena pada semester sebelumnya (semester I, II dan III) mereka sudah mendapatkan matakuliah dasar-dasar penulisan dan editing, fotografi, manajemen editorial, serta beberapa matakuliah yang dapat menambah wawasan serta keterampilan mahasiswa di bidang penulisan, seperti Penulisan Perekaman Realitas dan Penulisan
Respon realitas serta Penyuntingan Keterbacaan. Agar tidak tumpang tindih, dan agar semua aspek penting jurnalistik dapat tercakup, serta dapat saling melengkapi, diperlukan garisgaris besar program pengajaran (GBPP) yang terintegrasi antarmatakuliah yang berada dalam lingkup bidang jurnalistik.

Tabel 4 Matakuliah Semester IV

\begin{tabular}{lll}
\hline No & Matakuliah & SKS \\
\hline 1 & Pengantar Penulisan & 2 \\
& Kreatif & \\
2 & Penulisan Cerita Pendek & 2 \\
3 & Pemasaran Penerbitan & 2 \\
4 & Kewirausahaan & 3 \\
5 & Kalkulasi Penerbitan & 3 \\
6 & Digital Grafis & 3 \\
7 & Penyuntingan Isi & 3 \\
8 & Resensi Buku, Film, dan & 2 \\
& Musik & \\
9 & Penulisan Profil/Biografi & 2 \\
\hline Jumlah SKS & 23 \\
\hline
\end{tabular}

Tabel 5 Matakuliah Semester V

\begin{tabular}{|c|c|c|}
\hline No & Matakuliah & SKS \\
\hline 1 & Desain Media & 3 \\
\hline 2 & $\begin{array}{l}\text { Kewirausahaan } \\
\text { Penerbitan }\end{array}$ & 3 \\
\hline 3 & $\begin{array}{l}\text { Pemasaran Penerbitan } \\
\text { Terpadu }\end{array}$ & 3 \\
\hline 4 & $\begin{array}{l}\text { Teknik Penulisan } \\
\text { Laporan }\end{array}$ & 2 \\
\hline 5 & Bahasa Jurnalistik & 3 \\
\hline 6 & Manajemen Redaksi & 3 \\
\hline 7 & Jurnalistik Publik & 2 \\
\hline 8 & $\begin{array}{l}\text { Jurnalistik Radio dan } \\
\text { Televisi }\end{array}$ & 2 \\
\hline 9 & Jurnalistik Sastrawi & 2 \\
\hline \multicolumn{2}{|c|}{ Jumlah SKS } & 23 \\
\hline
\end{tabular}


Tabel 6 Matakuliah Semester VI

\begin{tabular}{lll}
\hline No & Matakuliah & SKS \\
\hline 1 & Praktik Industri & 4 \\
2 & Tugas Akhir & 6 \\
\hline Jumlah SKS & 10 \\
\hline
\end{tabular}

\section{Prospek Kerja Lulusan}

Berikut adalah peluang karier orang yang terampil di bidang penulisan kreatif dan bidang jurnalistik: Administrator Web, Alamat Sahabat Pena, Artikel Bahan Ceramah, Biografi, Bookmark, Brosur Public Relations, Brosur Perawatan Anak, Buku Biasa, Buklet Ringkas Bahasa, Buku Anak, Buku Teks/ Pelajaran, Catatan Harian, Cerita Bersambung, Cerita Pendek, Co-author, Company Profile, Club News Services, Daftar Harga, Daftar Nama dan Alamat, Data Alumni, Directory Apa dan Siapa, Dongeng, Dummy Buku, E-book, E-card, Elearning, Fillers, Flier, Ice Breaking, Ide Cerita, Indeks Buku, Latihan Soal, Karya Tulisan Tangan, Khotbah, Kolumnis, Komik, Kop dan Amplop Surat, Kuis, Literary Agent, Logo, Mailing List, Managing Editor, Media Internal, Melayani Komplen, Membeli/Menjual Space, Memo, Mengumpulkan Surat, Naskah Iklan, Naskah untuk Sinetron TV, Naskah Sandiwara/Drama, News Letter, Notulen Rapat/ PowerPoint Seminar, Novel, Wartawan Lepas, Novelet, Paper/Makalah, Panduan Golf, Panduan Orang Tua, Panduan Naik Gunung, Panduan Perjalanan, Panduan Wisata, Pantun, Pengantar Buku, Pengumuman, Penulis
Bayangan(Ghost Writer), Penyunting Naskah, Peribahasa, Tulisan Politik, Proof Reader, Poster, PowerPoint Ceramah, Proposal, Puisi, Reporter Lokal, Resensi, Resume, Ringkasan Buku, Riset, Riwayat Pribadi, Sejarah Kelahiran, Sinopsis Buku, Skripsi/Tesis/Disertasi, Surat Tulisan Tangan, Surat Kontrak, Surat Fans/Penggemar, Surat Sosial, Sinopsis Sinetron/Film, Syair Lagu, Tulisan di Truk/Angkutan, Teks Pidato, Kumpulan Tulisan (Bunga Rampai), Kartu Ucapan Ulang Tahun, Kartu Ucapan Datangnya Musim (Season Greeting), Kartu Ucapan Hari Libur, Kartu Ucapan Hari Raya Keagamaan, Tulisan di Spanduk/ Billboard, Tulisan Peringatan dan Penanggulangannya

Senarai peluang karier tersebut menunjukkan bahwa orang yang cerdas di bidang word smart punya masa depan yang cerah. Terampil dalam salah salah satu ragam tulisan, misalnya jurnalistik sastrawi, dapat merambah banyak lapangan pekerjaan. Terdapat begitu banyak ragam tulisan yang ditulis dengan kaidah dan prinsip-prinsip jurnalistik sastrawi. Karena itu, sudah bukan zamannya lagi orang yang masih memandang bahwa seseorang yang masuk jurusan jurnalistik atau Fakultas Ilmu Komunikasi pada umumnya, kariernya hanya menjadi wartawan. Tersedia banyak bidang pekerjaan, sebab di masa depan industri kreatif yang mengandalkan atau yang dasarnya adalah keterampilan olah kata, akan semakin berkembang dan dihargai. 
Tingkat Ketertarikan Mahasiswa Prodi Penerbitan terhadap

Peminatan Penulisan Kreatif dan Jurnalistik

\section{Penulisan Kreatif}

Dari perhitungan analisis terhadap kemampuan menulis Kreatif Mahasiswa diperoleh Skor: untuk nilai mean atau rata-rata sebesar 74,26 nilai median sebesar 76,00 dengan modus sebesar 78 dan standar deviasi/simpangan bakunya sebesar 12,584, sedangkan nilai minimum sebesar 48 dan nilai maksimum sebesar 98 .

Tabel 7 Kemampuan Menulis

\begin{tabular}{|l|r|}
\multicolumn{2}{|c|}{ Kreatif } \\
Malid & 36 \\
Mean & 0 \\
Media & 73.06 \\
Mode & 75.00 \\
Std. Deviation & $76^{\mathrm{a}}$ \\
Variance & 12.930 \\
Range & 167.197 \\
Minimum & 52 \\
Maximum & 44 \\
Sum & 96 \\
\end{tabular}

a. Multiple modes exist. The smallest value is shown

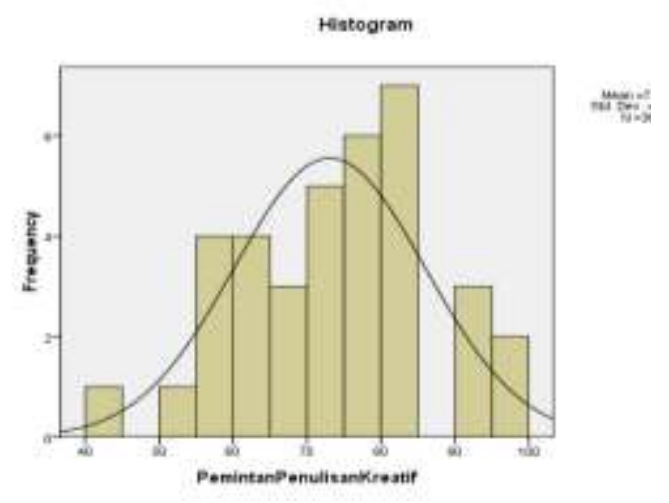

Gambar 1: Histogram dan Frekuensi Poligon Kemampuan Menulis Kreatif Mahasiswa

\section{Peminatan Penulisan Jurnalistik}

Dari perhitungan analisis terhadap kemampuan menulis Jurnalistik Mahasiswa diperoleh skor: untuk nilai mean atau rata-rata sebesar 73,06 nilai median sebesar 75,00 dengan modus sebesar 76 dan standar deviasi/simpangan bakunya sebesar 12,930, sedangkan nilai minimum sebesar 44 dan nilai maksimum sebesar 96 .

Tabel 8 Kemampuan Menulis Jurnalistik

\begin{tabular}{|l|r|}
\hline \multicolumn{1}{|c|}{ Valid } & 39 \\
Mean & 0 \\
Media & 74.26 \\
Mode & 76.00 \\
Std. Deviation & 78 \\
Variance & 12.584 \\
Range & 158.354 \\
Minimum & 50 \\
Maximum & 48 \\
Sum & 98 \\
\hline
\end{tabular}

a. Multiple modes exist. The smallest value is shown 


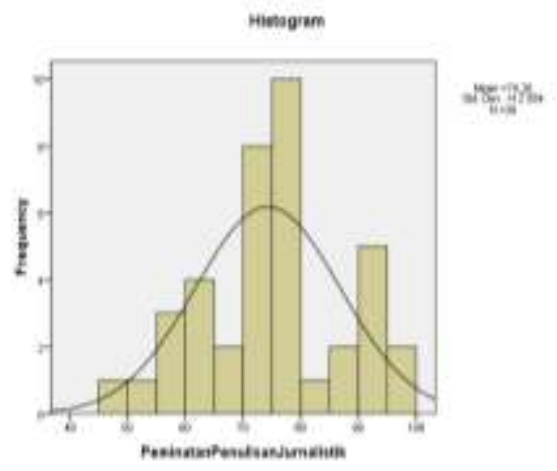

Gambar 2: Histogram dan Frekuensi Poligon Kemampuan Menulis Jurnalistik Mahasiswa

\section{Peminatan Penulisan Kreatif dan Penulisan Jurnalistik}

Dari perhitungan analisis terhadap kemampuan Menulis Kreatif dan Menulis Jurnalistik Mahasiswa diperoleh Skor: untuk nilai mean atau rata-rata sebesar 73,68 nilai median sebesar 76,00 dengan modus sebesar 76 dan standar deviasi/simpangan bakunya sebesar 12,679, sedangkan nilai minimum sebesar 44 dan nilai maksimum sebesar 98 .

Tabel 9 Kemampuan Menulis Kreatif dan Jurnalistik

\begin{tabular}{|l|r|}
\hline \multicolumn{1}{|c|}{ Valid } & 75 \\
Missing & 0 \\
Mean & 73.68 \\
Modia & 76.00 \\
Std. Deviation & $76^{\mathrm{a}}$ \\
Variance & 12.679 \\
Minimum & 160.761 \\
Maximum & 44 \\
Sum & 98 \\
\hline
\end{tabular}

a. Multiple modes exist. The smallest value is shown

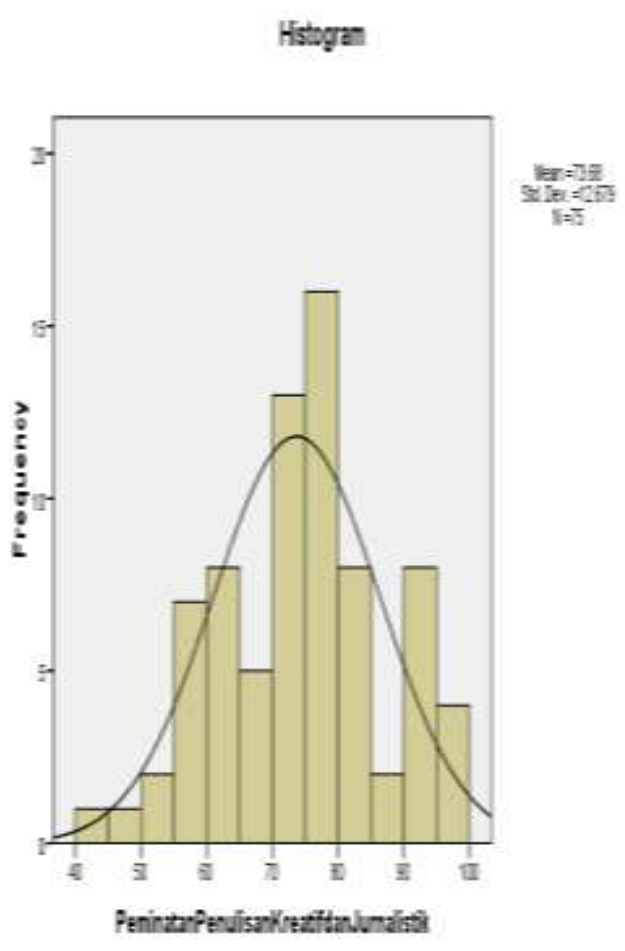

Gambar 4.3 Histogram dan Frekuensi Poligon Kemampuan Menulis Kreatif dan Menulis Jurnalistik Mahasiswa

Dari jumlah populasi pada tiga kelas, yaitu sebanyak 75 mahasiswa, peneliti menggunakan sampling penuh $(100 \%$ dari populasi mahasiswa Angkatan 6 pada Program Studi Penerbitan). Berdasarkan angket yang telah dibagikan, didapat 36 mahasiswa (sebanyak 48\%) berminat pada Penulisan Kreatif dan 39 mahasiswa (sebanyak 52\%) memiliki minat pada Penulisan Jurnalistik. Hasil ini membuktikan bahwa mahasiswa pada Program Studi Penerbitan memiliki minat yang cukup tinggi pada Peminatan Penulisan Kreatif dan Peminatan Jurnalistik. 


\section{PENUTUP}

Tujuan penelitian ini adalah untuk melakukan studi peminatan penulisan kreatif dan peminatan jurnalistik pada Program Studi Penerbitan Politeknik Negeri Media Kreatif. Pada akhirnya, berikut simpulan dalam penelitian ini.

Pertama, ada lima kompetensi yang menjadi alasan Prodi Penerbitan harus menyesuaiakan kurikulum yang sudah berjalan lima tahun ini, salah satunya dengan membuka Peminatan Penulisan Kreatif dan Peminatan Jurnalistik. Kelima kompetensi tersebut adalah penguasaan landasan dan wawasan pendidikan, Penguasaan substansi kajian prodi penerbitan yang menyangkut penguasaan substansi kajian setiap matakuliah, Penguasaan pembelajaraan bidang studi yang mendidik, penguasaan pengelolaan satuan matakuliah, dan pengembangan kepribadian dan keprofesionalan sebagai dosen.

Kedua, terkait Rancangan Peminatan Penulisan Kreatif, Matakuliah Dasar-Dasar Penulisan hendaknya pokok bahasan/ substansi materi yang wajib ada adalah proses kreatif sebuah tulisan, dari ide kosong (invention) sampai menjadi komoditas (industri). Mata rantai itu perlu jangan sampai tulisan kreatif berhenti sebagai naskah itu sendiri, tidak sampai sebagai industri kreatif. Juga perlu dibahas 4 interseksi media (tools, industry, society, dan content), agar penulisan kreatif tidak lepas dari konteks, yakni isi media, serta mediamorfosis. Sedangkan untuk
Rancangan Peminatan Jurnalistik, agar tidak tumpang tindih, dan agar semua aspek penting jurnalistik dapat tercakup, serta dapat saling melengkapi, diperlukan garis-garis besar program pengajaran (GBPP) yang terintegrasi antar-matakuliah yang berada dalam lingkup bidang jurnalistik.

Ketiga, terkait prospek kerja lulusan Penerbitan, Konsentrasi Penulisan Kreatif dan Penulisan Jurnalistik, setidaknya ada lebih dari 100 bidang pekerjaan yang dapat ditekuni.

Keempat, dari jumlah populasi pada tiga kelas, yaitu sebanyak 75 mahasiswa, peneliti menggunakan sampling penuh (100\% dari populasi mahasiswa Angkatan 6 pada Program Studi Penerbitan).

Berdasarkan angket yang telah dibagikan, didapat 36 mahasiswa (sebanyak 48\%) berminat pada Penulisan Kreatif dan 39 mahasiswa (sebanyak 52\%) memiliki minat pada Penulisan Jurnalistik. Hasil ini membuktikan bahwa mahasiswa pada Program Studi Penerbitan memiliki minat yang cukup tinggi pada Peminatan Penulisan Kreatif dan Peminatan Jurnalistik.

\section{DAFTAR RUJUKAN}

Kriyantono, Rachmat, 2008, Teknik Praktis dan Riset Komunikasi, Jakarta: Kencana Pranada Media Group.

Lubis, Effi Aswita, 2012, Metode Penelitian Pendidikan, Medan: UNIMED PRESS. 
Jurnal Publipreneur, Vol. 2, Nomor 4, Desember 2014, ISSN: 2338-5049

Mondry, 2008, Pemahaman Teori dan Praktik Jurnalistik, Bogor: Ghalia Indonesia.

Nawawi, Hadari, 2003, Metode Penelitian Bidang Sosial, Yogyakarta: Gajah Mada University Press.
Nurdin, 2005, Sistem Komunikasi Indonesia, Cetakan ke-2, Jakarta: Raja Grafindo Persada. Sareb Putra, R. Masri, 2010, Principle of Creative Writing, Jakarta: PT. Indeks. 